\title{
Spectrophotometric Determination of Citalopram Hydrobromide in Pharmaceuticals
}

\author{
Badiadka Narayana* and Kunnummel Veena
}

Department of Post Graduate Studies and Research in Chemistry, Mangalore University, Mangalagangothri - 574 199, Karnataka, India. Fax: +91-824-2287367.nbadiadka@yahoo.co.uk

Received November 11, 2009; accepted April 26, 2010

\begin{abstract}
Simple, rapid and sensitive methods are described for the spectrophotometric determination of citalopram hydrobromide (CIT) in pharmaceuticals. The method $\mathrm{A}$ is based on the oxidation of citalopram by a known excess of bromate-bromide mixture in hydrochloric acid medium, reduction of the residual oxidant by a fixed amount of iron(II) and the formation of iron(III)-thiocyanate-complex which is measured at $480 \mathrm{~nm}$. In the method B, 1,10-phenanthroline is used as a complexing agent and the formation of iron(II)-1,10-phenanthroline, which is measured at $510 \mathrm{~nm}$. The system obeys Beer's law in the concentration range of 1.0-7.0 $\mu \mathrm{g} \mathrm{mL}^{-1}$ of CIT for method A and 0.6-6.2 $\mu \mathrm{g} \mathrm{mL}^{-1}$ of CIT for method B. No interference observed from common pharmaceutical adjuvants. Both methods are equally precise as shown by the relative standard deviation values less than $2 \%$. The apparent molar absorptivities and Sandell's sensitivity for method A and $\mathrm{B}$ are found to be $2.10 \times 10^{4} \mathrm{~L} \mathrm{~mol}^{-1} \mathrm{~cm}^{-1}, 0.019 \mu \mathrm{g} \mathrm{cm}^{-2}, 7.30$ $\times 10^{4} \mathrm{~L} \mathrm{~mol}^{-1} \mathrm{~cm}^{-1}$ and $5.5 \times 10^{-3} \mu \mathrm{g} \mathrm{cm}^{-2}$, respectively. The methods have been successfully applied to the determination of citalopram hydrobromide in pure and dosage forms.
\end{abstract}

Keywords: Citalopram hydrobromide, spectrophotometry, bromatebromide mixture, thiocyanate, 1,10-phenanthroline.

\section{Introduction}

Citalopram is a selective and potent serotonin reuptake inhibitor with a very broad spectrum of therapeutic activity against depression, anxiety, obsessive and impulse control disorders $[1,2]$. Citalopram is a Pgp substrate and is actively transported by that protein from the brain. The efficiency of citalopram in people possessing a certain version of Pgp (genetic TT-allele) is likely to be diminished. This suggests that in non-responders to citalopram a switch to antidepressant which is not a Pgp substrate, such as fluoxetine (Prozac, Fontex) or mirtazapine (Remeron) - but not to venlafaxine (Effexor), amitriptyline (Elavil) or paroxetine (Paxil), which are Pgp substrates-may be beneficial [3]. Distinct from some other agents in its class, citalopram exhibits linear pharmacokinetics and minimal drug interaction potential, making it a better choice for the elderly or comorbid patients [4].

Citalopram should be taken with caution when using St John's wort, as resulting drug interactions could be adverse [5]. This may be caused by compounds in the plant extract reducing the efficacy of the hepatic cytochrome P450 enzymes that process citalopram. It has also been suggested that such compounds, including hypericin, hyperforin and flavonoids, could have SSRI-mimetic effects on the nervous system,
Resumen. Se describen dos métodos, simples y rápidos para la determinación espectrofotométrica del bomhidrato de citalopram (CIT) en fármacos. El método A está basado en la oxidación de citalopram mediante un exceso de mezcla bromato-bromuro en un medio de ácido clorhídrico, así como de la reducción del oxidante residual por una cantidad de hierro(II), y la formación del complejo de hierro(III)tiocianato, el cual se determina a $480 \mathrm{~nm}$. En el método B, se emplea la 1.10 -fenantrolina como agente complejante, y la formación de hierro(II)-1,10-fenantrolina se determina a $510 \mathrm{~nm}$. El sistema obedece la ley de Beer en un intervalo de concentración de 1.0-7.0 $\mu \mathrm{g}$ $\mathrm{mL}^{-1}$ de CIT para el método A, y de 0.6-6.2 $\mu \mathrm{g} \mathrm{mL}^{-1}$ de CIT para el método B. No se observa interferencia de la parte de aditivos farmacéuticos. Ambos métodos son igualmente precisos como lo muestran los valores menores de $2 \%$ de desviación estándar relativa. Se encuentran valores de $2.10 \times 10^{4} \mathrm{~L} \mathrm{~mol}^{-1} \mathrm{~cm}^{-1}, 0.019 \mu \mathrm{g} \mathrm{cm}^{-2}, 7.30 \times$ $10^{4} \mathrm{~L} \mathrm{~mol}^{-1} \mathrm{~cm}^{-1}$ y $5.5 \times 10^{-3} \mu \mathrm{g} \mathrm{cm}^{-2}$ para las absortividades molares y la sensibilidad de Sandell para los métodos A y B, respectivamente. Los métodos fueron utilizados exitosamente para la determinación de bromhidrato de citalopram en forma pura o en dosificación.

Palabras Claves: Bromhidrato de citalopram, espectrofotometría, mezcla bromato-bromuro, tiocianato, 1,10-fenantrolina.

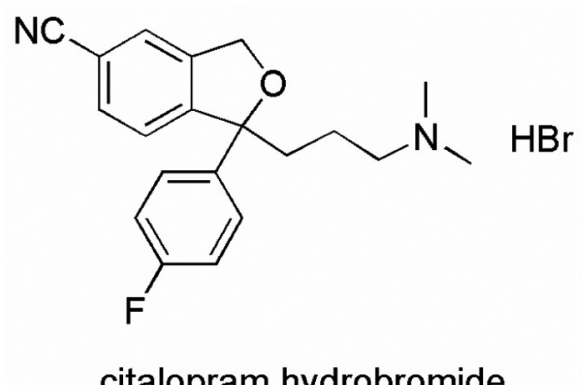

although this is still subject to debate [6]. One study found that hypericum extracts had similar effects in treating moderate depression as citalopram, with fewer side effects [7]. Several analytical methods have been reported for the determination of citalopram [8-21].

The development of new methods capable of determining drug concentration in pharmaceutical formulations and biological samples is important. The low cost and ease of operation make the spectrophotometric method highly desirable alternative for the assay of citalopram hydrobromide. Hence simple, sensitive and selective methods for the determination of citalopram hydrobromide have been developed and validat- 
ed according to ICH guidelines. The method is more sensitive than the existing methods and are free from such experimental variables such as heating or extraction step. The method rely on the use of simple, cheap chemicals and techniques but provide sensitivity comparable to that achieved by sophisticated and expensive technique like HPLC. Statistical analysis of the results indicates that the method yields exact values. Hence the proposed method has been successfully applied to the determination of citalopram in pharmaceutical samples.

\section{Results and Discussion}

In this method bromate in acid medium acts as an oxidizing agent and there is the formation of nascent oxygen. The formed nascent oxygen oxidizes bromide to bromine and the in situ generated bromine oxidizes the drug. The unreacted bromine is determined by two different scheme. The reduction of residual oxidant by iron(II) resulting in the formation of iron(III). In method A, resulting iron(III) is complexed with thiocyanate and measured at $480 \mathrm{~nm}$ (Figure 1). In method B, unreacted bromine is treated with a measured excess of iron(II) and remaining iron(II) is complexed with 1,10 phenanthroline and measured at $510 \mathrm{~nm}$ (Figure 2). Preliminary experiments were performed to fix the reagent concentration. In the present method all parameters influencing the color development were investigated and are incorporated in the recommended procedure.

In method A, citalopram when added in increasing concentration to a fixed concentration of bromate-bromide mixture, there was a decrease in the concentration of bromatebromide mixture. When known volume of $\mathrm{Fe}$ (II) was added to the same mixture, unreacted oxidant was reduced by a fixed amount of iron(II) and it showed a proportional decrease in the concentration of iron(III). The result could be observed by decrease in the absorbance with the increase in the concentration of citalopram at the respective $\lambda_{\max }$. In method B, citalopram when added in increasing concentration to a fixed con-

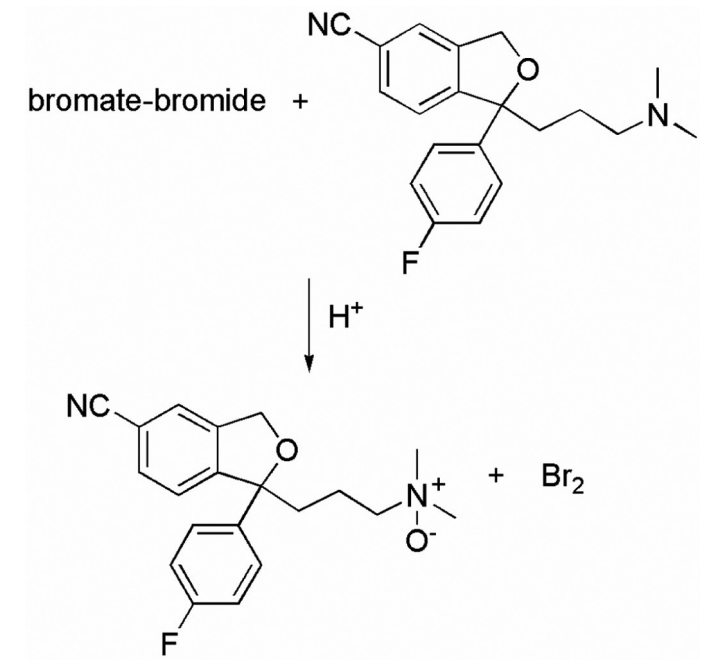

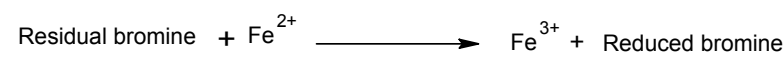

Method A

$$
\mathrm{Fe}^{3+}+6 \mathrm{SCN}^{-} \longrightarrow\left[\mathrm{Fe}(\mathrm{SCN})_{6}\right]^{3-}
$$

Method B

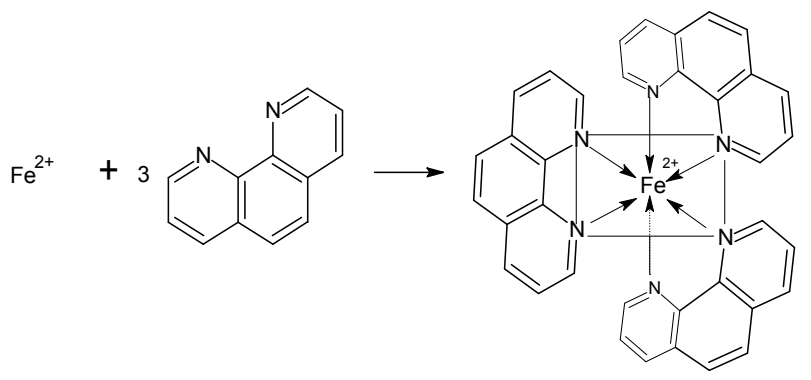

centration of bromate-bromide mixture, there was a decrease in the concentration of bromate-bromide mixture. When the decreasing amount of oxidant are reacted with a fixed amount of iron(II), it showed a proportional increase in the concentration of iron(II). As a result there is a proportional increase in the absorbance with the increasing concentration of the drug. Hydrochloric acid medium was found to be ideal for both the steps in method A and B, addition of excess of acid are not preferable since they would require large quantities of ammonia to raise the $\mathrm{pH}$ to 4 , required for iron(II)-phenanthroline complex formation.

\section{Analytical Data}

Adherence to Beer's law was studied by measuring the absorbance values of solutions varying in drug concentration. The analytical parameters such as molar absorptivity, Sandell's sensitivity, detection limit, quantitation limit, slope, intercept, correlation coefficients for method A and method B are incorporated in table 1 . The calibration graphs are described by the equation: $Y=a+b X$ (where $Y=$ absorbance, $a=$ intercept, $b=$ slope and $X=$ concentration in $\mu \mathrm{gml}^{-1}$ ) obtained by the method of least squares.

\section{Accuracy and Precision}

The accuracy and precision of the method was established by analyzing the pure drug solution at 5 different levels (within working limits). The results are summarized in table 3 and 4 .

\section{Interference Study}

In pharmaceutical analysis, it is important to test the selectivity towards the excipients added to the pharmaceutical preparations. Commonly encountered excipients such as glucose, 
Table 1. Analytical Parameters:

\begin{tabular}{lcc}
\hline & Method A & Method B \\
\hline$\lambda \max (\mathrm{nm})$ & 480 & 510 \\
Beer's law limit $\left(\mu \mathrm{gmL}^{-1}\right)$ & $1.0-7.0$ & $0.6-6.2$ \\
Molar absorptivity $\left(\mathrm{L} \mathrm{mol}^{-1} \mathrm{~cm}^{-1}\right)$ & $2.10 \times 10^{4}$ & $7.30 \times 10^{4}$ \\
Sandell's sensitivity $\left(\mu \mathrm{gcm}^{-2}\right)$ & 0.019 & $5.5 \times 10^{-3}$ \\
Limit of detection** $\left(\mu \mathrm{gmL}^{-1}\right)$ & 0.550 & 0.086 \\
Limit of quantification** $\left(\mu \mathrm{gmL}^{-1}\right)$ & 1.670 & 0.263 \\
Regression equation* & $Y=a+b X$ & \\
Slope $(b)$ & -0.006 & 0.038 \\
Intercept $(a)$ & 0.057 & 0.130 \\
Correlation coefficient $(\mathrm{r})$ & -0.9972 & 0.9751 \\
\hline
\end{tabular}

* $\mathrm{Y}$ is the absorbance and $\mathrm{X}$ is the concentration in $\left(\mu \mathrm{gmL}^{-1}\right)$

** calculated using ICH-Guidelines

Table 3. Evaluation of Accuracy and Precision Citalopram (Method A)

\begin{tabular}{ccccc}
\hline $\begin{array}{c}\text { Amount taken } \\
\left(\mu \mathrm{g} \mathrm{mL}^{-1}\right)\end{array}$ & $\begin{array}{c}\text { Amount found } \\
\left(\mu \mathrm{g} \mathrm{mL}^{-1}\right)\end{array}$ & $\begin{array}{c}\text { Recovery } \\
(\%)\end{array}$ & $\begin{array}{c}\mathrm{SD} \\
(\%)\end{array}$ & RSD \\
\hline 2.00 & 1.95 & 97.50 & 0.03 & 1.53 \\
3.00 & 2.95 & 98.33 & 0.04 & 1.36 \\
4.00 & 3.98 & 99.50 & 0.05 & 1.26 \\
5.00 & 4.99 & 99.80 & 0.03 & 0.60 \\
6.00 & 5.97 & 99.50 & 0.03 & 0.50 \\
\hline
\end{tabular}

${ }^{a}$ Average of five determinations, SD- standard deviation

starch, talc, lactose, sucrose did not interfere in the determination of CIT.

\section{Applications}

The proposed methods have been applied to the determination of citalopram in tablets. The results for the tablets were compared statistically with those of the tabulated value at $95 \%$ confidence level. The calculated student's t-test did not exceed the tabulated value. Table 2 gives the results of the determination from which it is clear that there is close agreement between the results obtained by the proposed methods and label claim. The parameters showing the sensitivity of the method such as molar absorptivity, Sandell's sensitivity were found to be higher compared with the existing method in the literature [22]. The low values of the relative standard deviation in percentages and the error indicated the high accuracy of the two methods.
Table 2. Results of Assay of Formulations by the Proposed methods

\begin{tabular}{ccll}
\hline Sample & $\begin{array}{c}\text { Labeled } \\
\text { amount }\end{array}$ & $\begin{array}{c}\text { Amount (method } \\
\text { A) found }(\mathrm{mg})\end{array}$ & $\begin{array}{c}\text { Amount (method } \\
\text { B) found }(\mathrm{mg})\end{array}$ \\
\hline Citalopram & 20.00 & 19.97 & 19.96 \\
& & $\%$ Label claim $\pm \mathrm{SD}$ & $\%$ Label claim \pm SD \\
& & $99.85 \pm 0.03$ & $99.80 \pm 0.06$ \\
& & ${ }^{b} t$ - test $=2.24$ & ${ }^{b}$ t-test $=1.49$ \\
\hline
\end{tabular}

${ }^{a}$ Average of five determinations, ${ }^{b}$ Tabulated t-value at $95 \%$ confidence level is 2.31 .

Citalopram tablet- Sun Pharmaceutical Industries

Table 4. Evaluation of Accuracy and Precision Citalopram (Method B)

\begin{tabular}{ccccc}
\hline Amount taken & Amount found $^{\mathrm{a}}$ & Recovery & $\mathrm{SD}$ & $\mathrm{RSD}$ \\
\hline 1.20 & 1.23 & 102.50 & 0.02 & 1.63 \\
1.40 & 1.39 & 99.28 & 0.01 & 0.72 \\
1.60 & 1.64 & 102.50 & 0.03 & 1.83 \\
1.80 & 1.77 & 98.33 & 0.02 & 1.13 \\
2.00 & 1.98 & 99.00 & 0.03 & 1.52 \\
\hline
\end{tabular}

a- Average of five determinations, SD- standard deviation

\section{Conclusions}

Simple, sensitive and selective spectrophotometric methods for the determination of citalopram hydrobromide have been developed and validated according to ICH guidelines. The developed methods have the advantage of sensitivity compared with the existing method in the literature [22]. The methods are easy to perform and do not contain any stringent experimental variables which effect the reliability of the results. There is no interference from common additives and excipients. The methods thus can be used in the determination of CIT in pure and dosage forms

\section{Experimental}

\section{Apparatus}

A Shimadzu UV-2550 UV-VIS Spectrophotometer with $1 \mathrm{~cm}$ matched quartz cells were used for the absorbance measurements.

\section{Reagents and Solutions}

All reagents used were of analytical reagent grade and distilled water was used for the preparation of all solutions. A 1000 


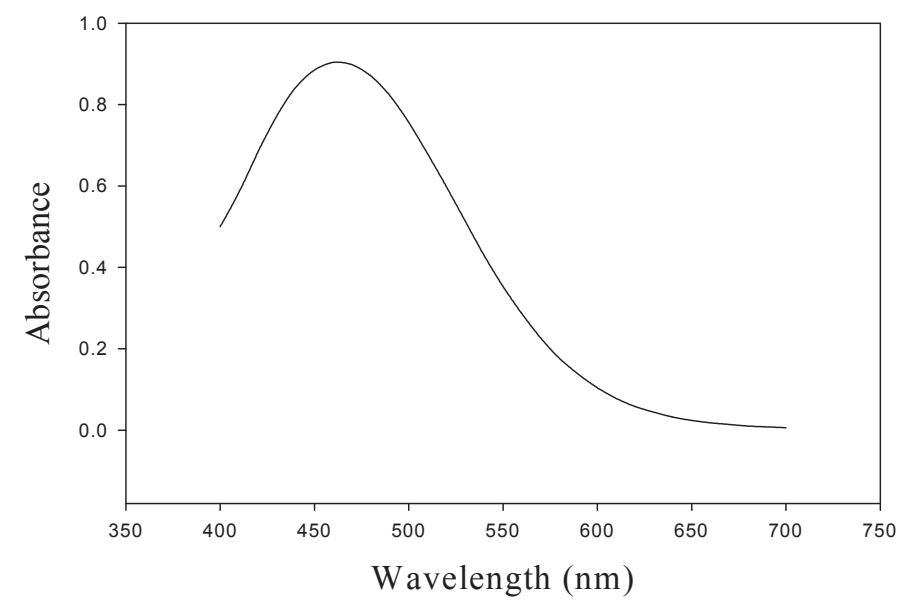

Fig. 1 Absorption Spectrum of Ferricyanide Complex (Method A)

$\mu \mathrm{g} \mathrm{mL} \mathrm{m}^{-1}$ standard drug solution of CIT was prepared in $50 \%$ ethanol and made up to the mark with distilled water and the stock solution was diluted appropriately to get the working concentration. Purity of the citalopram hydrobromide is found to be $99.51 \%$ (a gift sample from CAD Pharma Inc, India). Bromate-bromide mixture ( 30 and $50 \mu \mathrm{g} \mathrm{mL}^{-1}$ in $\mathrm{KBrO}_{3}$ ), ferrous ammonium sulphate (400 and $\left.350 \mathrm{ig} \mathrm{mL}^{-1}\right), 1,10$ phenanthroline $(0.3 \%)$, ammonia $(1: 1)$, thiocyanate $(1 \mathrm{M})$ were used.

\section{Spectrophotometric Method A}

Aliquots containing 1.0-7.0 $\mu \mathrm{g} \mathrm{mL}^{-1}$ of CIT were transferred into a series of $10 \mathrm{~mL}$ standard flasks using a micro burette. To this, $1 \mathrm{~mL}$ of $5 \mathrm{~mol} \mathrm{~L}^{-1} \mathrm{HCl}$ and bromate-bromide mixture (30 $\mu \mathrm{g} \mathrm{mL}^{-1}$ in $\mathrm{KBrO}_{3}$ ) were added. The contents were shaken well and were set aside for $5 \mathrm{~min}$ with occasional shaking. Then, $1 \mathrm{~mL}$ of $400 \mu \mathrm{g} \mathrm{mL}^{-1}$ ferrous ammonium sulphate was added and again the flask let stand for $15 \mathrm{~min}$ with occasional shaking followed by $3.5 \mathrm{~mL}$ of ammonium thiocyanate was added and diluted to the mark with distilled water, the absorbance of each solution was measured at $480 \mathrm{~nm}$ against the reagent blank.

\section{Spectrophotometric Method B}

Aliquots containing 0.6-6.2 $\mu \mathrm{g} \mathrm{mL}^{-1}$ of CIT were transferred into a series of $10 \mathrm{~mL}$ standard flasks using a micro burette. To this, $1 \mathrm{~mL}$ of $5 \mathrm{~mol} \mathrm{~L}^{-1} \mathrm{HCl}$ and bromate-bromide mixture $\left(50 \mu \mathrm{g} \mathrm{mL}^{-1}\right.$ in $\left.\mathrm{KBrO}_{3}\right)$ were added. The contents were shaken well and were set aside for 5 min with occasional shaking. Then, $1 \mathrm{~mL}$ of $350 \mu \mathrm{g} \mathrm{mL}^{-1}$ ferrous ammonium sulphate was added and again the flask let stand for 15 min with occasional shaking followed by $1 \mathrm{~mL}$ each of $0.3 \% 1,10$ phenanthroline and 1:1 $\mathrm{NH}_{3}$ solution were added and diluted to the mark with distilled water, and the absorbance of each solution was measured at $510 \mathrm{~nm}$ against the reagent blank.

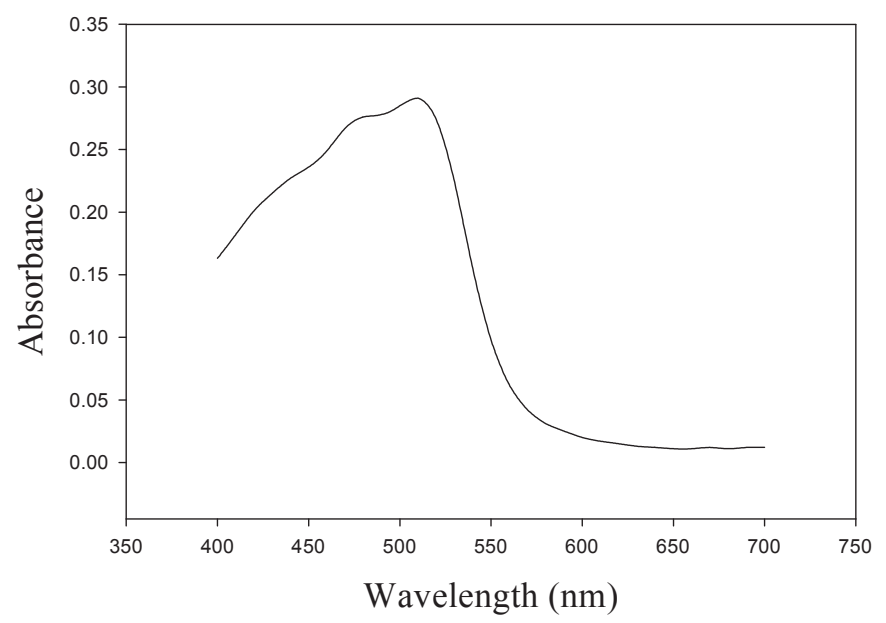

Fig. 2 Absorption Spectrum of Iron(II)- 1, 10-Phenanthroline Complex (Method B)

\section{Analysis of Dosage Forms}

To determine the content of citalopram in conventional tablets (label claim: $20 \mathrm{mg} /$ tablet), the sample stock solution was prepared by taking five tablets of citalopram equivalent to 100 $\mathrm{mg}$ were powdered using a mortar and pestle and transferring to a $100 \mathrm{~mL}$ volumetric flask by washing with ethanol. The solution was shaken for 30 min and filtered through Whatman no. 1 filter paper and the clear solution was made up to 100 $\mathrm{mL}$. Pipetted out $(2 \mathrm{~mL}$ for method A and $0.6 \mathrm{~mL}$ for method B) in to a $10 \mathrm{~mL}$ calibrated flasks, subjected to analysis by the proposed methods. The results are listed in table 2 .

\section{Acknowledgements}

One of the author KV thank UGC for providing JRF under UGC- Research Fellowship in Science for Meritorious Students Scheme. Authors thank UGC and DST, Govt of India for financial support through SAP and FIST programmes.

\section{References}

1. Fuller, R.W. J. Clin. Psychiatry 1986, 47, 4-8

2. Baumann, P. Int. Clin. Psychopharmacol. 1996, 11, 5-11

3. Uhr, M.; Tontsch, A.; Namendorf, C.; Ripke, S.; Lucae, S.; Ising, M.; Dose, T.; Ebinger, M.; Rosenhagen, M.; Kohli, M.; Kloiber, S.; Salyakina, D.; Bettecken, T.; Specht, M.; Pütz, B.; Binder, E.B.; Müller-Myhsok, B.; Holsboer, F. Neuron. 2008, 57, 203-209

4. Keller, M. B. J. Clin. Psychiatry 2000, 61, 896-908

5. Karch, A. Lippincott's Nursing Drug Guide. Philadephia, Baltimore, New York, London, Buenos Aires, Hong Kong, Sydney, Tokyo: Lippincott Williams \& Wilkins 2006.

6. http://www.umm.edu/altmed/articles/st-johns-000276.htm accessed Feb 272009

7. Gastpar, M.; Singer, A.; Zeller, K. Pharmacopsychiatry 2006, 39 , 66-75

8. Akerman, K. K.; Jolkkonen, J.; Huttunen, H.; Penttila, I. Ther. Drug. Moni. 1998, 20, 25-29 
9. Lacassie, E.; Gautier, J. M.; Marquet, P.; Rabatel, J. F.; Lachatre, G. J. Chromatogr. B. 2000, 742, 229-238

10. Lai, C.K.; Lee, I.; Au, K.M.; Chan, A.Y. M. Clin. Chem. 1997, 43, 312-320

11. Carlsson, B.; Norlander. J. Chromatogr. B. 1997, 702, 234-239

12. Trachta, G.; Schwarze, B.; Sagmuller, B.; Brehm, G.; Schneider, S. J. Mol. Struct. 2004, 693, 175-185

13. Frahnert, C.; Rao, M. L.; Grasmader, K. J. Chromatogr. B. 2003, 794, 35-47

14. Molander, P.; Thomassen, A.; Kristoffersen, L.; Greibrokk, T.; Lundanes, E. J.Chromatogr. B. 2001, 766, 77-87

15. Tournel G.; Houdret, N. ; Hedouin, V.; Deveaux, M.; Gosset, D.; Lhermitte, M. J. Chromatogr. B. 2001, 761, 147-158

16. Macek, J.; Ptacek, P.; Klima, J. J. Chromatogr. B. 2001, 755, 279285
17. Kosel, M.; Eap, C. B.; Amey, M.; Baumann, P. J. Chromatogr. B. 1998, 719, 234-238

18. Labat, L.; Deveaux, M.; Dallet, P.; Dubost, J.P. J .Chromatogr. B. 2002, 773, 17-23

19. Flores, J. R.; Nevado, J. J. B.; Salcedo, A. M. C.; Diaz, M. P. C. J. Sep. Sci. 2004, 27, 33-40

20. Andersen, S.; Halvorsen, S.; Pedersen- Bjergaard, K. E.; Ramussen, L.; Tanum H.; Refsum. J. Pharm. Biomed. Anal. 2003, 33, 263-273

21. Buzinkaiova, T.; Polonsky, J. J. Electrophoresis. 2000, 21, 28392841

22. Raza, A. Chem. Pharm. Bull. 2006, 54, $432-434$ 